\title{
PENINGKATAN AKTIVITAS DAN HASIL BELAJAR POLA-POLA HEREDITAS BIOLOGI MELALUI MODEL PEMBELAJARAN DIRECT INTRUCTION PADA SISWA KELAS XII IPA-3 SMA NEGERI 1 SITIUNG
}

\author{
Endang Safariyani
}

\author{
Guru SMAN 1 Sitiung Kabupaten Dharmasraya \\ Email: endang.safariyani@gmail.com
}

\begin{abstract}
This classroom action research raises the main problem, namely how to improve students' ability to solve problems of heredity patterns through the application of the Direct Instruction learning model in achieving biology learning competencies. The subjects of this study were students of class XII IPA-3 SMA Negeri 1 Sitiung. The method used by PTK and processed in a qualitative descriptive manner. The technique used to collect data is using an observation sheet as a data collection tool which is filled in by the observer during the learning process. From the results of the study, it can be concluded that the application of the Direct Instruction learning model in biology learning can increase student activity and learning outcomes in solving biological problems related to mathematical calculations, especially the matter of heredity patterns.
\end{abstract}

Keywords: Direct Intruction, calculations, learning outcomes

\begin{abstract}
Abstrak
Penelitian tindakan kelas ini mengangkat pokok masalah yaitu bagaimana meningkatkan kemampuan siswa dalam memecahkan soal pola-pola hereditas melalui penerapan model pembelajaran Direct Intruction dalam mencapai kompetensi belajar biologi. Subjek penelitian ini adalah siswa kelas XII IPA-3 SMA Negeri 1 Sitiung. Adapun metode yang digunakan PTK dan diolah secara deskriptif kualitatif. Teknik yang digunakan untuk mengumpulkan data menggunakan lembar observasi sebagai alat pengumpul data yang diisi oleh observer selama pembelajaran berlangsung. Dari hasil penelitian dapat disimpulkan bahwa penerapan model pembelajaran Direct Intruction dalam pembelajaran biologi dapat meningkatkan aktivitas dan hasil belajar siswa dalam memecahkan masalah biologi yang berhubungan dengan perhitungan matematika khususnya materi soal pola-pola hereditas.
\end{abstract}

Kata kunci: Direct Intruction, perhitungan matematika, hasil belajar.

\section{PENDAHULUAN}

Biologi merupakan ilmu yang mempelajari obyek dan persoalan gejala alam. Secara garis besar, biologi meliputi dua kegiatan utama, yaitu pengamatan untuk memperoleh bukti-bukti empirik dan proses penalaran untuk memperoleh konsepkonsep. Belajar biologi adalah suatu kegiatan untuk mengungkap rahasia alam yang berkaitan dengan makhluk hidup.

Pada sebagian besar di sekolah pembelajaran yang dilakukan cenderung terpusat pada guru (teacher center), kegiatan pembelajaran yang demikian disebut juga pembelajaran tradisional. Cara mengajar yang sering digunakan para guru biologi adalah ceramah pada setiap kegiatan belajar mengajar siswa hanya mendengar dan mencatat, sehingga siswa cenderung pasif dan merasa bosan. 
Apalagi materi itu menuntut siswa untuk dapat menganalisa materi yang berhubungan dengan perhitungan matematika, banyak diantara siswa yang kesulitan memahami materi-materi seperti ini, sehingga dari hasil ujian masih banyak nilai siswa berada dibawah KKM (Kriteria Ketuntasan Minimal) yang ditetapkan yaitu 75. Berdasarkan hasil wawancara dengan siswa langsung banyak siswa yang tidak mengerti langkah-langkah penyelesaian suatu masalah biologi khususnya pada pokok bahasan" Pola-pola Hereditas" dikelas XII.

Berhasilnya suatu pendidikan tergantung pada siswa sebagai objek dari kegiatan pembelajaran di sekolah dan juga tidak terlepas dari guru sebagai salah satu faktor yang memegang peranan penting dalam menentukan berhasil atau tidaknya pendidikan. Keberhasilan seorang guru tertuju pada proses belajar mengajar di kelas, selain itu peran guru dalam memotivasi siswa juga dapat menentukan peningkatan hasil belajar.

Pemilihan model pembelajaran yang tepat dan sesuai akan sangat membantu tercapainya tujuan pembelajaran. Proses pembelajaran yang lebih variatif dan melibatkan siswa untuk menjadi lebih aktif dan komunikatif. Penggunaan model pembelajaran yang kurang menarik dapat menimbulkan suatu masalah, yaitu motivasi belajar rendah sehingga berdampak pada hasil belajar. Penggunakan model pembelajaran yang dapat mendorong siswa untuk lebih aktif dalam proses pembelajaran seperti melalui model pembelajaran Direct Intruction.

Model Direct Intruction merupakan suatu model pengajaran yang dapat membantu siswa dalam mempelajari keterampilan dasar dan memperoleh informasi yang dapat diajarkan selangkah demi selangkah. Apabila menggunakan model pengajaran ini, guru mempunyai tanggung jawab untuk mengidentifikasi tujuan pembelajaran dan tanggung jawab yang besar terhadap penstrukturan isi/materi atau keterampilan, menjelaskan kepada peserta didik, pemodelan/mendemonstrasikan yang dikombinasikan dengan latihan, memberikan kesempatan pada siswa untuk berlatih menerapkan konsep atau keterampilan yang telah dipelajari serta memberikan umpan balik.

Berdasarkan latar belakang seperti yang diutarakan di atas menunjukkan bahwa selain memotivasi siswa juga di perlukan penggunaan model yang tepat untuk memungkinkan peningkatan prestasi belajar. Melalui penerapan model belajar Direct Intruction diharapkan siswa nantinya dapat memiliki kemampuan dalam menyelesaikan/memecahkan permasalahan soal-soal biologi khususnya materi "Pola-pola Hereditas". Oleh karena itu melihat fakta di atas penulis tertarik untuk melakukan penelitian ini dan menyusun laporan yang berjudul "Peningkatan Aktivitas Dan Hasil Belajar Siswa Pada Materi Pola-Pola Hereditas Biologi Dengan Penerapan Model Pembelajaran Direct Intruction Pada Siswa Kelas XII IPA-3 SMA Negeri 1 Sitiung."

Tujuan penelitian ini adalah: Dengan menerapkan model pembelajaran Direct Intruction diharapkan dapat meningkatkan aktivitas serta hasil belajar di kelas XII IPA 3 SMAN 1 Sitiung dalam kemampuannya memecahkan soal pola-pola hereditas biologi. Penelitian ini diharapkan dapat bermanfaat bagi berbagai pihak, antara lain: bagi siswa; penerapan model pembelajaran Direct Intruction diharapkan mampu meningkatkan aktivitas dan hasil belajar siswa dalam kemampuannya memecahkan soal pola-pola hereditas biologi di kelas XII IPA khususnya dikelas XII IPA-3. Bagi guru: penerapan model pembelajaran Direct Intruction dalam pembelajaran Biologi belum umum dilakukan oleh guru di 
sekolah. Oleh sebab itu, hasil penelitian ini dapat memberikan pengalaman langsung pada guru untuk menerapkan model pembelajaran yang lebih inovatif dalam pembelajaran Biologi. Bagi sekolah: penelitian ini diharapkan memberikan kontribusi terhadap peningkatan motivasi belajar dan hasil belajar siswa serta pengalaman baru bagi para guru untuk menerapkan model pembelajaran yang lebih inovatif dalam pembelajaran.

Hasil belajar merupakan tolak ukur yang dapat digunakan untuk menentukan tingkat keberhasilan siswa. Hasil belajar juga merupakan prestasi yang dicapai setelah mengikuti proses pembelajaran. Hasil evaluasi akan dilahirkan dalam bentuk penilaian angka ataupun huruf. Penilaian merupakan suatu alat untuk mengetahui keberhasilan proses dan hasil belajar siswa. Adapun tujuan penilaian menurut Suharsimi (1992) adalah: Untuk dapat mengetahui siswa-siswa mana yang berhak melanjutkan pelajaran karena sudah berhasil menguasai materi serta mampu mengetahui apakah metoda mengajar yang dugunakan sudah tepat atau belum. Disisi lain menurut Nana (2002) tujuan penilaian adalah untuk mengukur sejauh mana ketercapaian tujuan instruksional tersebut tentu disesuaikan dengan kurikulum yang berlaku. Proses belajar mengajar pada akhirnya akan mendatangkan suatu hasil akhir yang disebut dengan hasil belajar. Menurut Sudjana (2005) hasil belajar adalah suatu kemampuan yang dicapai siswa setelah melalui kegiatan belajar. Djamarah (1994) menyatakan bahwa hasil belajar adalah apa yang diperoleh siswa setelah melakukan aktifitas belajar.

Pembelajaran Direct Intruction khusus dirancang untuk mengembangkan belajar peserta didik tentang pengetahuan prosedural dan pengetahuan deklaratif yang dapat diajarkan dengan pola selangkah demi selangkah. Model ini merupakan suatu pendekatan mengajar yang dapat membantu peserta didik dalam mempelajari keterampilan dasar dan memperoleh informasi yang dapat diajarkan selangkah demi selangkah. Pendekatan mengajar ini sering disebut Model Pembelajaran Langsung. Apabila guru menggunakan model ini, guru mempunyai tanggung jawab untuk mengidentifikasi tujuan pembelajaran dan tanggung jawab yang besar terhadap penstrukturan isi/materi atau keterampilan, menjelaskan kepada peserta didik, pemodelan/mendemonstrasikan yang dikombinasikan dengan latihan, memberikan kesempatan pada peserta didik untuk berlatih menerapkan konsep atau keterampilan yang telah dipelajari serta memberikan umpan balik.

Model pembelajaran Direct Intruction dirancang khusus untuk menunjang proses belajar peserta didik yang berkaitan dengan pengetahuan prosedural dan pengetahuan deklaratif yang terstruktur dengan baik, yang dapat diajarkan dengan pola kegiatan yang bertahap, selangkah demi selangkah. Pelajaran dengan model pembelajaran Direct Intruction berjalan melalui lima fase: (1) penjelasan tentang tujuan dan mempersiapkan peserta didik, (2) pemahaman/presentasi materi ajar yang akan diajarkan atau demonstrasi tentang keterampilan tertentu, (3) memberikan latihan terbimbing, (4) mengecek pemahaman dan memberikan umpan balik, (5) memberikan latihan mandiri (sumber: www.hariyono.org ).

Langkah-langkah model Pembelajaran Direct Instruction adalah sebagai berikut:

1) Menyampaikan tujuan dan mempersiapkan peserta didik.

2) Mendemonstrasikan pengetahuan dan ketrampilan.

3) Membimbing pelatihan. 
4) Mengecek pemahaman dan memberikan umpan balik.

5) Memberikan kesempatan untuk latihan lanjutan

Sintak dari model Direct Instruction adalah:

1) Sajian informasi kompetensi,

2) Mendemontrasikan pengetahuan dan ketrampilan procedural,

3) Membimbing pelatihan-penerapan,

4) Mengecek pemahaman dan balikan,

5) Penyimpulan dan evaluasi,

6) Refleksi.

Kelebihan dari model Direct Instruction adalah:

1) Peserta didik benar-benar dapat menguasai pengetahuannya.

2) Semua peserta didik aktif / terlibat dalam pembelajaran.

Kekurangan dari model Direct Instruction adalah:

1) Memerlukan waktu lama sehingga peserta didik yang tampil tidak begitu lama.

2) Hanya untuk mata pelajaran tertentu.

(sumber: www.hariyono.org ).

Berdasarkan rumusan masalah, kajian teori, maka hipotesis dalam penelitian ini adalah: Penerapan model pembelajaran Direct Intruction di SMAN I Sitiung dapat meningkatkan aktivitas dan hasil belajar siswa khususnya kemampuan dalam memecahkan soal pola-pola hereditas biologi di kelas XII IPA 3 semester 1 Tahun Pelajaran 2014/2015.

\section{METODOLOGI PENELITIAN}

Penelitian ini menggunakan penelitian tindakan kelas karena penelitian tindakan kelas merupakan penelitian yang lebih sesuai dengan tugas pokok dan fungsi guru, meningkatkan kualitas pembelajaran, meningkatkan kualitas peserta didik, serta mencapai tujuan pembelajaran atau pendidikan. Penelitian Tindakan Kelas (PTK) merupakan bentuk kajian yang bersifat reflektif oleh pelaku tindakan, dilakukan untuk meningkatkan kematangan rasional dari tindakantindakan dalam melakukan tugas, memperdalam pemahaman terhadap tindakantindakan yang dilakukan itu, serta memperbaiki kondisi tempat praktek pembelajaran tersebut dilakukan.

Penelitian tindakan kelas ini dilakukan pada semester satu tahun pelajaran 2014-2015 untuk mata pelajaran biologi di SMA Negeri 1 Sitiung Kabupaten Dharmasraya. Siswa yang menjadi obyek penelitian kelas XII IPA-3 berjumlah 31 orang terdiri dari 7 orang laki-laki dan 24 orang perempuan. Dalam melaksanakan penelitian peneliti dibantu oleh observer. Penelitian ini dilaksanakan dari tanggal 10 September sampai 30 Desember 2014. Pelaksanaan penelitian dilakukan dalam dua siklus masing-masing siklus 2 kali pertemuan, dengan jadwal penelitiannya sebagai berikut:

1. Pra Siklus dilaksanakan pada Tanggal 15 Oktober 2014 dengan materi Prinsip-prinsip Hereditas Mendel. Waktu selama 2 jam pelajaran.

2. Siklus I dilaksanakan pada tanggal 22 dan 29 Oktober 2014 dengan materi Pola-pola Hereditas (Penyimpangan Semu Hukum Mendel dan Penerapan Hukum Mendel dalam Pewarisan Sifat ) waktu selama 4 (empat) jam pelajaran. 
3. Siklus II dilaksanakan pada tanggal 1 dan 5 November 2014 dengan materi Pola-pola Hereditas(Pautan dan Pindah Silang, Determinasi Seks, dan Gen letal), waktu selama 4 (empat) jam pelajaran.

Perencanaan ini dilaksanakan berdasarkan program semester dan masih menggunakan kurikulum KTSP. Materi ajar disesuaikan dengan KTSP SMAN I Sitiung. Materi pembelajaran adalah Pola-pola Hereditas (Prinsip-prinsip Hereditas Mendel, Hukum Mendel I dan II, Penyimpangan Semu Hukum Mendel, Pautan dan Pindah Silang, Determinasi Seks, dan Gen letal). Penelitian tindakan kelas ini dilaksanakan dalam 2 siklus dengan setiap siklus terdiri dari 2 kali pertemuan. Setiap kali pertemuan proses pembelajaran dengan menggunakan model pembelajaran Direct Intruction. Setiap siklus secara garis besar dengan langkah-langkah sebagai berikut :

1. Tahap Perencanaan

Sebelum melaksanakan penelitian, peneliti melakukan berbagai persiapan awal, yaitu :

a. Menyusun jadwal kegiatan pembelajaran di kelas.

b. Membuat rencana pelaksanaan pembelajaran (RPP).

c. Merancang kegiatan pembelajaran dengan menerapkan model pembelajaran Direct Intruction

d. Membagi siswa dalam kelompok-kelompok kecil yang masing-masing kelompok terdiri dari 2-3 orang dengan latar belakang yang bervariasi, baik jenis kelamin, tingkat kecerdasan, suku, agama dan tingkat kecerdasan biologinya.

e. Masing-masing kelompok berembuk untuk menentukan siapa yang menjadi ketua kelompok.

2. Tahap Pelaksanaan Tindakan

a. Siswa dikondisikan untuk mengikuti model pembelajaran Direct Intruction.

b. Guru menyampaikan tujuan dan mempersiapkan siswa dalam kelompoknya masing-masing.

c. Guru menyampaikan pengetahuan awal dan keterampilan dalam menganalisa materi, bisa juga ditayangkan melalui Power Point.

d. Guru memberikan contoh pelatihan soal dan memberi kesempatan siswa untuk memahami konsep materi yang disampaikan.

e. Guru mengecek pemahaman dengan cara memberi umpan balik.

f. Masing-masing kelompok menyampaikan hasil latihannya. Dan guru memberikan penjelasan/penegasan materi sesuai dengan tujuan pembelajaran yang ingin dicapai.

g. Guru memberi kesempatan untuk latihan lanjutan.

3. Tahap Pengamatan

Tahap pengamatan dilakukan pada saat kegiatan sedang berlangsung. Pada penelitian ini peneliti menggunakan lembar observasi mengenai motivasi siswa dalam belajar Biologi dan lembar observasi kegiatan guru dengan masing-masing menerapkan model pembelajaran Direct Intruction. Lembar observasi siswa berisi aktivitas belajar yang meliputi: 1) Siswa bertanya mengenai cara menyelesaikan soal-soal pola hereditas saat proses pembelajaran berlangsung, 2) Siswa menjawab pertanyaan dari soal-soal pola hereditas saat diskusi antar kelompok. 3)Siswa mengerjakan latihan soal yang 
diberikan guru, 4) Siswa berbicara tentang masalah lain saat pembelajaran berlangsung, 5) siswa diam saja saat proses belajar sedang berlangsung, 6) siswa tidak konsentrasi saat proses belajar berlangsung, 7) siswa diberi pujian atau penguatan oleh guru, dan 8) Siswa dibantu secara individual dalam menyelesaikan soal-soal pola hereditas dalam kelompok kecil.

4. Tahap Refleksi

Guru dan observer menganalisis dan merefleksi pelaksanaan hasil tindakan I. Untuk keperluan analisis ini dilakukan kegiatan antara lain memeriksa lembar observasi. Hasil analisis dan refleksi terhadap tindakan I ini menjadi bahan pelaksanaan tindakan berikutnya. Berikutnya dilanjutkan dengan pelaksanaan pembelajaran siklus II dengan bertitik tolak pada hasil refleksi pada siklus I. Kemudian menganalisis dan melakukan refleksi keseluruhan tindakan pembelajaran dengan menerapkan model pembelajaran Direct Intruction. Kegiatan ini merupakan akhir dari tindakan I sampai tindakan II.

Penelitian ini menggunakan lembar observasi sebagai alat pengumpul data yang diisi oleh observer selama pembelajaran berlangsung. Pengumpulan data dengan observasi, yaitu untuk memperoleh informasi bagaimana pembelajaran Biologi dengan menerapkan model pembelajaran Direct Intruction, observasi meliputi bagaimana pelaksanaan aktivitas belajar siswa. Selain itu diberikan tes tiap akhir siklus, tes bertujuan untuk melihat hasil belajar siswa pada aspek kognitif. Dalam penyusunan tes peneliti mengkonsultasikan dengan observer. Tes dan kuis tersebut terdiri dari soal-soal dalam bentuk essay dan objektif. Dalam penyusunan tes tersebut penulis melakukan langkah-langkah untuk memenuhi validitas sebagai berikut :

1) Menentukan tujuan mengadakan tes, yaitu untuk mendapatkan hasil belajar siswa.

2) Membuat pembatasan terhadap bahan yang akan diujikan.yaitu batasan mengenai materi pelajaran yang dituangkan dalam kisi-kisi soal tes, kisikisi soal tes siklus I, dan kisi-kisi soal tes siklus II

3) Menyusun butir-butir soal yang akan diujikan berbentuk essay dan objektif.

Teknik analisis data yang dipergunakan adalah penyajian data, penarikan simpulan, serta verifikasi refleksi. Untuk melihat kecenderungan aktivitas siswa belajar biologi, data yang terkumpul pada lembar pengamatan dianalisis dengan cara menghitung persentase aktivitas belajar siswa dengan menggunakan rumus teknik proporsi (Sudjana, 1996). Sedangkan ketuntasan belajar diukur dengan menggunakan kriteria belajar yang tercantum dalam buku pedoman analisis hasil belajar Depdikbud (1994:6) yaitu:

1) Siswa dikatakan tuntas belajar jika siswa tersebut telah menguasai $65 \%$ dari materi yang diuji.

2) Siswa dikatakan tuntas secara klasikal jika $85 \%$ dari pengikut tes telah menguasai materi $65 \%$ dari materi yang diajarkan.

\section{HASIL PENELITIAN DAN PEMBAHASAN Deskripsi Kondisi Awal}

Kondisi awal di kelas XII IPA 3 SMAN Negeri 1 Sitiung terkait dengan model pembelajaran yang digunakan oleh guru dalam mata pelajaran biologi antara lain pertama, kebanyakan siswa kurang bisa mengerjakan soal-soal yang berhubungan dengan perhitungan matematika. Kedua, metode pembelajaran 
monoton dan teacher centered atau lebih berpusat pada guru menimbulkan siswa bosan. Ketiga, rendahnya kemampuan siswa dalam memecahkan soal-soal yang berhubungan dengan materi pola-pola hereditas, sehingga siswa cenderung pasif. Dari 31 siswa terdapat 20 siswa diam saja dalam belajar serta 26 siswa yang perlu mendapat bimbingan/bantuan secara individual dalam penyelesaian soal.

\section{Deskripsi Siklus Pertama}

Dalam pembelajaran yang berlangsung pada siklus pertama materi pola-pola Hereditas (Penyimpangan Semu Hukum Mendel dan Penerapan Hukum Mendel dalam Pewarisan Sifat ). Materi yang diajarkan terindentifikasi cukup jelas, siswa belum terbiasa dengan model pembelajaran Direct Intruction sehingga guru kelihatan masih dominan dalam membimbing siswa memecahkan permasalahan. Akan tetapi kelihatan motivasi siswa mulai tumbuh dalam memecahkan soal soal yang diberikan, walaupun belum sesuai dengan yang diharapkan. Dan untuk melihat kecenderungan motivasi siswa dalam belajar biologi ini, data yang terkumpul pada lembar pengamatan dianalisis dengan cara menghitung persentase aktivitas belajar siswa. Peningkatan aktivitas dan hasil belajar siswa dapat dilihat pada tabel di bawah ini.

Tabel: 1. Hasil observasi Aktivitas Belajar Siswa Dalam Menyelesaikan Soal-Soal Pola Hereditas Pada Siklus Pertama

\begin{tabular}{|c|c|c|c|c|c|}
\hline \multirow[t]{2}{*}{ No } & \multirow[t]{2}{*}{ Aktivitas siswa } & \multicolumn{2}{|c|}{ Pertemuan } & \multirow{2}{*}{$\begin{array}{l}\text { Rata- } \\
\text { rata }\end{array}$} & \multirow[t]{2}{*}{$\%$} \\
\hline & & 1 & 2 & & \\
\hline 1 & $\begin{array}{l}\text { Siswa bertanya mengenai cara } \\
\text { menyelesaikan soal-soal pola hereditas } \\
\text { saat proses pembelajaran berlangsung }\end{array}$ & 15 & 20 & 17.5 & 67 \\
\hline 2 & $\begin{array}{l}\text { Siswa menjawab pertanyaan dari soal- } \\
\text { soal pola hereditas saat diskusi antar } \\
\text { kelompok }\end{array}$ & 15 & 18 & 16.5 & 63 \\
\hline 3 & $\begin{array}{l}\text { Siswa mengerjakan latihan soal yang } \\
\text { diberikan guru }\end{array}$ & 18 & 22 & 20.0 & 77 \\
\hline 4 & $\begin{array}{l}\text { Siswa berbicara tentang masalah lain } \\
\text { saat pembelajaran berlangsung }\end{array}$ & 3 & 2 & 2.5 & 10 \\
\hline 5 & $\begin{array}{l}\text { Siswa diam saja saat proses } \\
\text { pembelajaran berlangsung }\end{array}$ & 10 & 8 & 9.0 & 35 \\
\hline 6 & Siswa tidak konsentrasi saat belajar & 8 & 5 & 6.5 & 25 \\
\hline 7 & $\begin{array}{l}\text { Siswa diberi pujian atau penguatan } \\
\text { oleh guru saat belajar }\end{array}$ & 7 & 10 & 8.5 & 33 \\
\hline 8 & $\begin{array}{l}\text { Siswa dibantu secara individual dalam } \\
\text { menyelesaikan soal-soal pola hereditas } \\
\text { dalam kelompok kecil }\end{array}$ & 20 & 18 & 19.0 & 73 \\
\hline & Rata-rata & & & 12.4 & \\
\hline
\end{tabular}

(Sumber: Jurnal pembelajaran guru)

Pada Tabel.1 terlihat bahwa aktivitas belajar siswa dalam pembelajaran biologi pada siklus I mengalami peningkatan dan aktivitas buruk yang biasa dilakukan peserta didik saat belajar mengalami penurunan untuk pengamatan pada indikator siswa yang bertanya mengenai cara menyelesaikan soal-soal pola 
hereditas saat proses pembelajaran berlangsung hanya 67\%, siswa menjawab pertanyaan dari soal-soal pola hereditas saat diskusi antar kelompok adalah 63\%, Siswa mengerjakan latihan soal yang diberikan guru adalah $77 \%$, siswa berbicara tentang masalah lain saat kerja kelompok atau saat pembelajaran berlangsung adalah 10\%, siswa diam saja saat proses belajar sedang berlangsung(karena tidak mengerti) adalah 35\%, siswa tidak konsentrasi saat proses belajar berlangsung adalah 25\%, siswa diberi pujian atau penguatan oleh guru adalah $33 \%$, siswa dibantu oleh guru secara individual dalam menyelesaikan soal-soal pola hereditas dalam kelompok kecil adalah $73 \%$.

\section{Refleksi Siklus Pertama}

Hasil analisis siklus pertama ini dijadikan bahan untuk memperbaiki tindakan yang akan diberikan berikutnya. Beberapa hal positif yang dapat dikemukakan dari siklus pertama adalah adanya siswa yang bertanya mengenai cara menyelesaikan soal-soal pola hereditas dan menjawab penyelesaikan soal-soal pola hereditas saat pembelajaran berlangsung yaitu siswa yang bertanya mengenai cara menyelesaikan soal-soal pola hereditas saat proses pembelajaran berlangsung hanya $67 \%$, siswa menjawab dari soal-soal pola hereditas saat diskusi antar kelompok hanya $63 \%$. Sedangkan hal yang bersifat negatif dari aktivitas belajar siswa adalah masih ada siswa tidak mengerjakan latihan soal yang diberikan guru, berbicara masalah lain saat kerja kelompok, diam saja saat proses belajar berlangsung (karena tidak mengerti), tidak konsentrasi saat belajar sehingga masih banyak siswa yang dibantu secara individual oleh guru.

\section{Deskripsi Siklus Kedua}

Berdasarkan hasil refleksi siklus pertama maka untuk memperbaiki kelemahan-kelemahan pada siklus kedua ini tetap memperlakukan hal yang sama seperti pada siklus pertama yaitu melakukan model pembelajaran Direct Intruction dengan materi yang sesuai dengan program semester yaitu Pola-pola Hereditas. Perencanaan tindakan pada siklus kedua berdasarkan refleksi siklus pertama hal yang perlu mendapat perhatian yaitu masih rendahnya aktivitas belajar siswa dalam hal bertanya maupun menjawab pertanyaan sehubungan dengan materi yang dipelajari, Siswa yang tidak mengerjakan latihan soal yang diberikan guru, berbicara masalah lain saat kerja kelompok, diam saja saat proses belajar berlangsung(karena tidak mengerti), dan tidak konsentrasi saat belajar. Secara umum aktivitas siswa belajar biologi pada siklus kedua mengalami peningkatan dibanding dengan siklus pertama. Pada siklus kedua ini tampak siswa mengalami peningkatan pemahaman materi yang dipelajari. Berdasarkan pengamatan data analisis terhadap aktivitas siswa belajar biologi maka pada siklus kedua ditemukan hal-hal sebagai berikut :

- Siswa lebih berani bertanya mengenai langkah-langkah dalam mengerjakan latihan soal pola-pola hereditas.

- Siswa sudah mulai terbiasa dengan model pembelajaran Direct Intruction

- Keberlangsungan pembelajaran sudah sesuai dengan rencana pelaksanaan pembelajaran.

- Pemberian penghargaan kepada siswa/kelompok yang mempunyai aktivitas terbesar menumbuhkan semangat dan mendorong terhadap penguasaan materi. 
Persentase aktivitas siswa belajar biologi pada siklus kedua dapat dilihat pada Tabel 2 berikut.

Tabel: 2. Hasil observasi Aktivitas Belajar Siswa Dalam Menyelesaikan Soal-Soal Pola Hereditas Pada Siklus Kedua

\begin{tabular}{|c|l|c|c|c|c|}
\hline No & \multicolumn{1}{|c|}{ Aktivitas siswa } & \multicolumn{2}{|c|}{ Pertemuan } & Rata-rata & \% \\
\cline { 3 - 4 } & & 1 & 2 & & \\
\hline $\mathbf{1}$ & $\begin{array}{l}\text { Siswa bertanya mengenai cara } \\
\text { menyelesaikan soal-soal pola hereditas } \\
\text { saat proses pembelajaran berlangsung }\end{array}$ & 15 & 8 & 11.5 & 44 \\
\hline $\mathbf{2}$ & $\begin{array}{l}\text { Siswa menjawab pertanyaan dari soal- } \\
\text { soal pola hereditas saat diskusi antar } \\
\text { kelompok }\end{array}$ & 18 & 24 & 21.0 & 81 \\
\hline $\mathbf{3}$ & $\begin{array}{l}\text { Siswa mengerjakan latihan soal yang } \\
\text { diberikan guru }\end{array}$ & 24 & 26 & 25.0 & 96 \\
\hline $\mathbf{4}$ & $\begin{array}{l}\text { Siswa berbicara tentang masalah lain } \\
\text { saat pembelajaran berlangsung }\end{array}$ & 1 & 0 & 0.5 & 2 \\
\hline $\mathbf{5}$ & $\begin{array}{l}\text { Siswa diam saja saat proses } \\
\text { pembelajaran berlangsung }\end{array}$ & 8 & 3 & 5.5 & 21 \\
\hline $\mathbf{6}$ & Siswa tidak konsentrasi saat belajar & 2 & 0 & 1.0 & 4 \\
\hline $\mathbf{7}$ & $\begin{array}{l}\text { Siswa diberi pujian atau penguatan oleh } \\
\text { guru saat belajar }\end{array}$ & 15 & 22 & 18.5 & 71 \\
\hline $\mathbf{8}$ & $\begin{array}{l}\text { Siswa dibantu secara individual dalam } \\
\text { menyelesaikan soal-soal pola hereditas } \\
\text { dalam kelompok kecil }\end{array}$ & 8 & 3 & 5.5 & 21 \\
\hline & Rata-rata & & & 11.1 & \\
\hline
\end{tabular}

(Sumber: Jurnal pembelajaran guru)

Tabel 2 di atas, menunjukkan bahwa aktivitas siswa belajar biologi mengalami peningkatan. Siswa yang bertanya mengenai cara menyelesaikan soal-soal pola hereditas saat proses pembelajaran berlangsung $44 \%$, hal ini menurun karena banyak siswa yang sudah mengerti langkah-langkah penyelesaian soal pola-pola hereditas sehingga mereka sangat serius dalam mengerjakan latihan, siswa menjawab pertanyaan dari soal-soal pola hereditas saat diskusi antar kelompok $81 \%$, Siswa mengerjakan latihan soal yang diberikan guru 96\%, siswa berbicara tentang masalah lain saat pembelajaran berlangsung $2 \%$, siswa diam saja saat proses belajar sedang berlangsung $21 \%$ hal ini mengalami penurunan karena sudah banyak siswa yang mengerti dalam memecahkan soal pola-pola hereditas, siswa tidak konsentrasi saat proses belajar berlangsung menjadi $4 \%$, siswa diberi pujian atau penguatan oleh guru $71 \%$, siswa dibantu oleh guru secara individual dalam menyelesaikan soal-soal pola hereditas dalam kelompok kecil $21 \%$.

\section{Refleksi Siklus Kedua}

Beberapa hal positif yang dapat dikemukakan dari siklus kedua adalah siswa sudah mengerti langkah-langkah pengerjaan soal-soal pola hereditas(soal genetika) sehingga jumlah siswa yang bertanya mengenai cara pengerjaan soal 
latihan menurun dan siswa sangat serius dalam mengerjakan latihan, siswa menjawab pertanyaan dari soal-soal pola hereditas saat diskusi antar kelompok meningkat $81 \%$ dari $63 \%$ pada siklus pertama. Tidak ada lagi siswa yang berbicara masalah lain dan tidak berkosentrasi saat belajar pada akhir siklus II. Walaupun masih ada siswa yang tetap harus dibimbing secara individual dalam mengerjakan latihan soal-soal pola hereditas.

\section{Deskripsi Hasil Penelitian Terhadap Hasil Belajar Siswa Deskripsi Hasil Belajar Siklus I}

Data kalkulasi nilai harian sebagai hasil belajar siswa pada siklus I adalah sebagai berikut:

Tabel.3 Data rata-rata hasil belajar siswa dalam menyelesaikan soal-soal pola hereditas pada akhir siklus I $(\mathrm{KKM}=75)$

\begin{tabular}{|c|c|c|c|c|}
\hline No & Nilai & Jumlah Siswa & Tuntas & Tidak Tuntas \\
\hline 1 & $<49$ & 0 & 0 & 0 \\
\hline 2 & $50-59$ & 7 & 0 & 7 \\
\hline 3 & $60-69$ & 11 & 0 & 11 \\
\hline 4 & $70-79$ & 7 & 2 & 5 \\
\hline 5 & $80-89$ & 3 & 3 & 0 \\
\hline 6 & $90-100$ & 3 & 3 & 23 \\
\hline \multicolumn{5}{|l}{} \\
\hline \multicolumn{7}{l}{ (Sumber: Tabulasi data Oktober 2014) } & 8 & 74.19 \\
\hline
\end{tabular}

Dari total rata-rata perolehan nilai siswa walau sudah mengalami peningkatan tiap pertemuan, tapi rataan totalnya masih belum mencapai nilai KKM yaitu 75 , dan persentase yang tuntas baru mencapai $26 \%$. Hal ini membuat harus ada perbaikan pada siklus berikutnya baik pelatihan kembali cara memecahkan soalsoal pola-pola hereditas di awal belajar siswa maupun penguatan di akhir tiap pertemuan.

\section{Refleksi Siklus I}

Berdasarkan hasil pengamatan dari pelaksanaan pembelajaran ditemukan halhal seperti di bawah ini:

1) Siswa kurang mempersiapkan diri belajar dan mengerti penjelasan guru di awal pembelajaran yang mengakibatkan mereka masih ada yang mengelami kesulitan memahami materi yang ditugaskan.

2) Sebagian siswa kemampuan untuk memecahkan permasalahan biologi khususnya soal-soal aplikasi dari persilangan hukum mendel.

3) Sebagian besar siswa sangat antusias mengikuti pembelajaran model pembelajaran Direct Intruction.

\section{Deskripsi Hasil Belajar Siklus II}

Data kalkulasi nilai harian sebagai hasil belajar siswa pada siklus II adalah sebagai berikut:

Tabel.4 Data rata-rata hasil belajar siswa dalam menyelesaikan soalsoal pola hereditas pada akhir siklus II (KKM = 75)

\begin{tabular}{|c|c|c|c|c|}
\hline No & Nilai & Jumlah Siswa & Tuntas & Tidak Tuntas \\
\hline $\mathbf{1}$ & $<49$ & 0 & 0 & 0 \\
\hline $\mathbf{2}$ & $50-59$ & 0 & 0 & 0 \\
\hline
\end{tabular}




\begin{tabular}{|c|c|c|c|c|}
\hline $\mathbf{3}$ & $60-69$ & 1 & 0 & 1 \\
\hline $\mathbf{4}$ & $70-79$ & 4 & 3 & 1 \\
\hline $\mathbf{5}$ & $80-89$ & 14 & 14 & 0 \\
\hline $\mathbf{6}$ & $90-100$ & 12 & 12 & 0 \\
\hline & jumlah & 31 & 29 & 2 \\
\hline \multicolumn{2}{|l|}{ Persentase } & 93.55 & 6.45 \\
\hline \multicolumn{4}{|l}{ Sumber: Tabulasi data November 2014) } \\
\hline
\end{tabular}

Dari total rata-rata perolehan nilai siswa sudah mengalami peningkatan, persentase ketuntasan sudah mecapai $93.55 \%$. Hal ini membuat siswa semakin antusias untuk terus belajar dan berdiskusi membahas materi pelajaran menggunakan model pembelajaran Direct Intruction. Sedangkan data perbandingan kalkulasi nilai harian sebagai hasil belajar siswa pada siklus I dan II adalah sebagai berikut:

Tabel 5. Kalkulasi Hasil Tes Siklus I dan II

\begin{tabular}{|l|c|c|c|c|}
\hline \multirow{2}{*}{} & \multicolumn{2}{|c|}{ Siklus I } & \multicolumn{2}{c|}{ Siklus II } \\
\cline { 2 - 5 } & Pertemuan 1 & Pertemuan 2 & Pertemuan 1 & Pertemuan 2 \\
\hline Jumlah & 1918 & 2281 & 2577 & 2874 \\
\hline $\begin{array}{l}\text { Ketuntasan } \\
\text { Klasikal(\%) }\end{array}$ & 16 & 45 & 77 & 97 \\
\hline Rata-rata & 62 & 74 & 83 & 93 \\
\hline
\end{tabular}

(Sumber: Tabulasi data November 2014

Dari tabel 1 di atas, setelah dianalisis, terlihat bahwa ketuntasan klasikal persiklus pada mata pelajaran biologi mengalami peningkatan sesuai KKM yang ditentukan yaitu 75. Pada siklus I ketuntasan klasikal pertemuan $\mathrm{I}=16 \%$ dan pertemuan II $=45 \%$, sedangkan pada siklus II meningkat pada pertemuan I $=77$ $\%$ dan pertemuan II meningkat menjadi $97 \%$. Data hasil belajar yang diperoleh dikatakan meningkat apabila hasil belajar yang diperoleh dari siklus kedua lebih tinggi dari hasil belajar siklus pertama. Pada penelitian ini peneliti menggunakan hasil tes ulangan harian sebagai titik awal untuk melihat peningkatan pada hasil belajar siswa. Dari tabel di atas, setelah dianalisis, di atas terlihat bahwa rata-rata nilai siswa mengalami peningkatan. Pada siklus I rata-rata dari 62 pada pertemuan I meningkat menjadi 74 pada pertemuan 2, sedangkan pada siklus II adalah 83 pada pertemuan 1 dan meningkat menjadi 93 pada pertemuan 2.

\section{Pembahasan Setiap Siklus}

Dengan memperhatikan hasil observasi terhadap aktivitas siswa dalam pembelajaran biologi menggunakan model pembelajaran Direct Intruction menunjukkan adanya peningkatan dalam kemampuan siswa memahami materi khususnya materi pola-pola hereditas. Dari hasil belajarpun siswa menunjukkan peningkatan dilihat dari rata-rata hasil belajar yang didapatkan yaitu rata-rata dari 62 meningkat menjadi 74 pada siklus I, dan rata-rata 83 meningkat menjadi 93 pada siklus II. Hal ini menunjukkan model pembelajaran Direct Intruction sangat efektif dipakai dalam materi biologi yang berhubungan dengan perhitungan matematika dan studi kasus khususnya materi pola-pola hereditas.

Hasil belajar yang didapatkan siswa merupakan tolak ukur yang dapat digunakan untuk menentukan tingkat keberhasilan siswa. Hasil belajar juga merupakan prestasi yang dicapai setelah mengikuti proses pembelajaran. Hal ini 
sesuai dengan pendapat Oemar H (2005) yang menyatakan bahwa," Hasil belajar adalah perubahan tingkah laku pada diri siswa yang dapat diamati dan diukur dalam bentuk perubahan sikap dan keterampilan. Perubahan tersebut diartikan terjadinya peningkatan dan pengembangan".

Penerapan model pembelajaran Direct Intruction dianggap perlu dilakukan agar dapat membantu siswa dalam mempelajari suatu konsep materi dengan pemahaman yang lebih terutama materi tersebut berhubungan dengan perhitungan matematika dan terjadinya peningkatan aktivitas siswa karena dengan menerapkan model pembelajaran Direct Intruction seluruh siswa dapat terlibat aktif dalam proses pembelajaran. Model pembelajaran Direct Intruction ini memiliki kelebihan yaitu: 1) Peserta didik benar-benar dapat menguasai pengetahuannya, 2) Semua peserta didik aktif/terlibat dalam pembelajaran. Sedangkan kekurangannya yaitu: 1) Memerlukan waktu lama sehingga peserta didik yang tampil tidak begitu lama, dan 2) hanya untuk mata pelajaran tertentu (sumber: www.hariyono.org ).

\section{KESIMPULAN DAN SARAN \\ Kesimpulan}

Berdasarkan hasil pengolahan data pengamatan siswa belajar biologi pada setiap siklus, maka kesimpulan penelitian adalah:

1. Melalui penerapan model pembelajaran Direct Intruction menunjukkan adanya peningkatan dalam aktivitas dan kemampuan siswa memahami materi khususnya materi pola-pola hereditas.

2. Model pembelajaran Direct Intruction sangat efektif dipakai dalam materi biologi yang berhubungan dengan perhitungan matematika dan studi kasus khususnya materi pola-pola hereditas.

3. Rata -rata hasil belajar yang didapatkan mengalami peningkatan yang sangat signifikan yaitu rata-rata pada siklus I, dari 62 pada pertemuan 1 meningkat menjadi 74 pada pertemuan 2, dan rata-rata pada siklus II, dari 83 pada

\section{Saran} pertemuan 1 meningkat menjadi 93 pada pertemuan 2 .

1. Model pembelajaran Direct Intruction agar diterapkan pada materi biologi yang berhubungan dengan perhitungan matematika secara berkelanjutan.

2. Perlu diadakan penelitian yang sejenis lebih lanjut.

\section{DAFTAR RUJUKAN}

Djamarah. 1994. Prestasi Belajar dan Kompetensi Guru. Usaha Nasional: Surabaya.

Nana Sudjana. 2002. Dasar-dasar Proses Belajar Mengajar. Bandung: Sinar Baru hlm.2

Oemar Hamalik.2005. Perencanaan Pengajaran berdasarkan Pendekatan Sistem. Jakarta: Bumi Aksara

Purwanto, 2004. Prinsip-Prinsip dan Teknik Evaluasi dalam Belajar.Bandung: Rosad Karya.

Suharsimi Arikunto. 1992. Dasar-dasar Evaluasi Pendidikan. Jakarta: Bumi Aksara

Sudjana.N.2005. Penilaian Hasil Proses Belajar Mengajar. Remaja Rosdakarya: Bandung. 
Standar Kompetensi dan Kompetensi Dasar Tingkat SMA Bidang Studi Biologi. 2006. Jakarta: Departemen Pendidikan Nasional.

-. 2011. Model Pembelajaran Explicit Instruction (on line). (http://www.hariyono.org /2011/10/model-pembelajaran-explicitinstruction.html). Diakses tanggal 2 September 2014. 